\title{
PENGEMBANGAN LEMBAR KERJA BERBASIS INKUIRI PADA ANALISIS KAFEIN BERBAGAI BAHAN BAKU MINUMAN
}

\author{
Rahmawati Dwi Pratiwi ${ }^{1}$ \\ 1 Pendidikan Kimia Fakultas Tarbiyah dan Keguruan UIN Sunan Gunung Djati \\ Bandung Jl. A.H Nasution No.105 Cibiru-Bandung 46014 Indonesia \\ E-mail: rahmapratiwi.rp@gmail.com
}

\begin{abstract}
ABSTRAK
Penelitian ini dilatar belakangi oleh perlunya melakukan pengembangan lembar kerja berbasis inkuiri pada materi praktikum Kimia Organik yaitu analisis kafein dalam minuman. Bahan baku minuman mengandung kafein yang digunakan dalam penelitian adalah biji cokelat, biji kopi, dan daun teh. Metode penelitian ini adalah Research and Development yang terdiri dari dua tahap yaitu perencanaan dan pengembangan. Pada tahap perencanaan dihasilkan prosedur analisis kafein secara kualitatif dengan metode Parry, pemisahan senyawa kafein dan analisis kuantitatif dengan spektrofotometer UV-Vis. Pada tahap pengembangan dihasilkan lembar kerja berbasis inkuiri diturunkan dari prosedur analisis kafein yang telah dilakukan di Laboratorium. Lembar kerja inkuiri hasil pengembangan ini memiliki karakteristik yaitu adanya wacana, pertanyaan dan tugas yang mendorong kegiatan berinkuiri serta dilengkapi dengan rubrik penilaian untuk mengukur proses dan produk yang dihasilkan oleh peserta didik. Lembar kerja berbasis inkuiri pada analisis kafein dari berbagai bahan baku minuman dinyatakan layak digunakan dalam pembelajaran dengan nilai ratarata $r_{\text {hitung }} 0,8$. Hasil analisis kafein dari berbagai bahan baku minuman menunjukkan kondisi optimum proses ekstraksi dicapai dengan menggunakan pelarut kloroform yaitu biji kopi memiliki kadar kafein tertinggi dengan nilai rata-rata sebesar 1,007\%. Dengan demikian, lembar kerja berbasis inkuiri dapat digunakan dalam praktikum Kimia Organik khususnya pada materi pemisahan senyawa organik kafein.
\end{abstract}

Kata kunci: Inkuiri, kafein, bahan baku minuman.

\section{ABSTRACT}

The purpose of this research is develop inquiry-based worksheets on the material Organic Chemistry experiment that caffeine analysis in the beverages. In the research raw material beverages containing caffeine used are cocoa beans, coffee beans and tea leaves. This research design is Research and Development method, which consists of two phase such as planning and development. In planning phase is resulted procedures qualitative analysis of caffeine with Parry's method, extraction of caffeine and quantitative analysis with spectrophotometer UV-Vis. In development phase is resulted inquiry-based worksheets from procedures caffeine analysis. Characteristic of inquiry-based worksheets is discourse, question and task that motivated inquiry's activity and equipped with an assessment rubric to measure processes and products for student. Inquiry-based worksheets of caffeine analysis from various raw material beverages suitable to use in learning with average value of $r_{\text {count }}$ is 0.8 . The results of caffeine analysis showed the optimum condition from extraction caffeine using chloroform is coffee beans with average value caffeine content is $1.007 \%$.

Keywords: Inquiry, caffeine, raw material beverages.

\section{PENDAHULUAN}


Pembelajaran kimia adalah salah satu tahapan pembelajaran yang dapat dilakukan melalui eksperimen atau praktikum, sehingga peserta didik dapat melibatkan keterampilan proses sains seperti mengamati, mengklasifikasi, menafsirkan, meramalkan, menggunakan alat dan bahan, menerapkan konsep, merencanakan percobaan, mengajukan pertanyaan, mengomunikasikan dan menyimpulkan (Yunita, 2012: 9). Lembar kerja eksperimen yang dapat menunjang keterampilan proses sains adalah lembar kerja berbasis inkuiri. Hal ini dikarenakan, lembar kerja eksperimen berbasis inkuiri akan melibatkan peserta didik dalam merumuskan masalah, menentukan hipotesis dari masalah tersebut, menentukan variabel yang diteliti, merancang percobaan, mengumpulkan dan menganalisis data, hingga menyimpulkan hasil percobaan (Joyce dan Weil, 2009: 206).

Lembar kerja berbasis inkuiri dapat diterapkan pada praktikum mengenai analisis kafein. Analisis kafein merupakan contoh konsep dari materi pemisahan senyawa organik yang dipelajari dalam mata kuliah Praktikum Kimia Organik.

Biji cokelat, biji kopi dan daun teh merupakan jenis tanaman yang digunakan sebagai bahan baku minuman. Sudah lama, masyarakat mengenal dan mengonsumsi bahan baku minuman ini. Bahkan di negara Jepang dan Cina terdapat tradisi meminum teh yang disebut dengan chanoyu. Namun, masih banyak masyarakat yang belum mengetahui bahwa didalam cokelat, kopi, dan teh tersebut mengandung kafein (Erwin, 2009: 15).

Salah satu analisis kafein yang dapat dilakukan yaitu analisis secara kuantitatif untuk menentukan kadar kafein. Dalam analisis kuantitatif ini, diperlukan proses ekstraksi kafein. Menurut, Varma (2010: 12) bahwa kafein dapat diekstraksi menggunakan pelarut organik seperti, kloroform, etil asetat, diklorometan, dan metil klorida. Namun, di laboratorium penggunaan metil klorida dalam ekstraksi kafein ini tidak dianjurkan karena sifatnya yang sangat membahayakan bagi kesehatan tubuh.

Merujuk pada penelitian yang dilakukan oleh Arwangga (2016: 113) bahwa belum terdapatnya penentuan kadar kafein dari berbagai bahan baku minuman dan penentuan pelarut organik yang paling optimum dalam menghasilkan kadar kafein. Oleh karena itu, untuk mengisi praktikum kimia organik yang belum optimal, perlu dikembangkan lembar kerja yang dapat memfasilitasi mahasiswa pada eksperimen analisis kafein dari berbagai bahan baku minuman yang dapat mengembangkan keterampilan proses sains.

\section{METODE PENELITIAN}

Metode yang digunakan dalam penelitian ini adalah perencanaan dan pengembangan (Research and Development) yang terdiri dari dua tahap, yaitu define (perencanaan) dan develop (pengembangan). Pada tahap define dilakukan persiapan dalam membuat lembar kerja seperti menganalisis materi dan literatur mengenai pemisahan senyawa organik kafein serta merancang prosedur mengenai analisis kafein. Pada tahap develop dilakukan pengembangan prosedur analisis kafein hingga dihasilkan lembar kerja yang akan diuji kelayakannya kepada dosen dan mahasiswa.

Teknik pengumpulan data yang digunakan berupa angket uji kelayakan yang diberikan kepada dosen dan mahasiswa berisi saran mengenai lembar kerja.

Teknik pengolahan data didasarkan pada angket uji kelayakan dan kriteria skala lajuan untuk menentukan layak dan tidaknya lembar kerja yang telah dibuat dengan mencari nilai $r_{\text {hitung }}$ melalui persamaan:

Keterangan:

$$
r=\frac{x}{N \cdot n}
$$

$\mathrm{x}=$ Bobot jawaban responden

$r=$ Nilai kelayakan

$\mathrm{n}=$ Jumlah responden

$\mathrm{N}=$ Jumlah item

Menurut Sugiyono (2010: 353) apabila nilai /hitung lebih besar dari nilai / / kritis yaitu 0,30 maka instrumen dikatakan valid dan sebaliknya, jika nilai /hitung kurang dari $r_{\text {kritis }}$ maka instrumen dikatakan tidak valid. Interpretasi mengenai besarnya nilai validasi (/hitung) disajikan pada Tabel 1 berikut.

Tabel 1 Interpretasi Nilai Kelayakan ( $r)$

\begin{tabular}{|c|c|l|}
\hline No & Nilai Kelayakan $(r)$ & \multicolumn{1}{|c|}{ Interpretasi } \\
\hline 1 & $0,80 \geq r \leq 1,00$ & Tinggi \\
\hline 2 & $0,60 \geq r \leq 0,80$ & Cukup Tinggi \\
\hline 3 & $0,40 \geq r \leq 0,60$ & Agak Rendah \\
\hline 4 & $0,20 \geq r \leq 0,40$ & Rendah \\
\hline 5 & $0,00 \geq r \leq 0,20$ & Sangat Rendah \\
\hline
\end{tabular}

\section{HASIL DAN PEMBAHASAN}

Pada pengembangan lembar kerja ini dilakukan penelitian di Laboratorium Terpadu UIN Sunan 
Gunung Djati Bandung untuk mendapatkan prosedur analisis kafein dari berbagai bahan baku minuman yang dilakukan pada 25 Januari hingga 15 April 2016.

Pada tahap define dihasilkan rancangan eksperimen analisis kafein mulai dari penentuan bahan baku minuman yang mengandung kafein, analisis secara kualitatif dengan metode Parry, pemisahan senyawa kafein, dan terakhir analisis kuantitatif dengan spektofotometer UV-Vis. Analisis kafein secara kualitatif dengan metode Parry dilakukan dengan tujuan untuk membuktikan keberadaan kafein dalam sampel (biji cokelat, kopi, dan daun teh yang telah dihaluskan sebelumnya) dengan menambahkan pereaksi Parry dan amonia (Depkes RI, 1995: 165). Terjadinya perubahan warna hijau/biru yang dihasilkan pada larutan sampel menandakan bahwa secara kualitatif sampel positif mengandung kafein (Maramis, dkk., 2013: 124). Setelah sampel terbukti mengandung kafein, dilakukan pemisahan senyawa kafein dengan cara ekstraksi kontinu dan ekstraksi cair-cair. Dalam proses ekstraksi kontinu ini dilakukan dengan alat soklet. Sebanyak 25 gram sampel bahan baku minuman yang telah dihaluskan dibungkus dengan kertas saring kemudian dimasukkan kedalam tabung soklet yang telah dihungungkan dengan kondensor. Dilakukan proses ekstraksi hingga cairan yang berada dalam tabung soklet menjadi bening. Larutan hasil ekstraksi soklet ditambahkan $\mathrm{Na}_{2} \mathrm{CO}_{3}$ kemudian dimasukkan kedalam corong pisah untuk dilakukan proses ekstraksi cair-cair. Dimasukkan sebanyak $25 \mathrm{~mL}$ kloroform kedalam corong pisah dan dilakukan ekstraksi sebanyak 4 kali. Selanjutnya, diuapkan dengan rotary evaporator. Dilakukan hal yang sama dengan menambahkan pelarut etil asetat. Dalam proses ini digunakan dua pelarut organik yaitu kloroform dan etil asetat yang bertujuan untuk mengetahui pelarut yang paling optimum dalam menghasilkan kadar kafein yang tinggi pada sampel. Setelah itu, dilakukan analisis kafein secara kuantitatif dengan spektrofotometer UV-Vis. Analisis ini bertujuan untuk menentukan kadar kafein yang terdapat dalam berbagai bahan baku minuman pada panjang gelombang maksimal $275 \mathrm{~nm}$. Kadar kafein yang dihasilkan dari proses ekstraksi sampel dengan penambahan pelarut kloroform ditunjukkan pada tabel 2 berikut.

Tabel 2 Kadar kafein dalam sampel dengan penambahan kloroform

\begin{tabular}{|c|c|c|c|c|}
\hline Sampel & Abs & $\begin{array}{c}\text { Konsentrasi } \\
\text { (mg/l) }\end{array}$ & $\begin{array}{c}\text { \% } \\
\text { Kafein }\end{array}$ & $\begin{array}{c}\text { Rata- } \\
\text { Rata }\end{array}$ \\
\hline $\begin{array}{c}\text { Biji } \\
\text { Cokelat }\end{array}$ & 1,467 & 26,373 & 0,351 & \multirow{2}{*}{0,349} \\
\cline { 2 - 4 } & 1,457 & 26,145 & 0,348 & \\
\hline
\end{tabular}

\begin{tabular}{|c|c|c|c|c|}
\hline & 1,455 & 26,109 & 0,348 & \\
\hline \multirow{3}{*}{ Biji Kopi } & 3,871 & 70,036 & 0,933 & \multirow{3}{*}{1,007} \\
\cline { 2 - 4 } & 3,866 & 69,945 & 0,932 & \\
\cline { 2 - 4 } & 4,781 & 86,580 & 1,154 & \\
\hline \multirow{3}{*}{$\begin{array}{c}\text { Daun } \\
\text { Teh }\end{array}$} & 3,568 & 64,527 & 0,860 & \multirow{3}{*}{0,860} \\
\cline { 2 - 4 } & 3,559 & 64,363 & 0,858 & \\
\cline { 2 - 4 } & 3,565 & 64,472 & 0,860 & \\
\hline
\end{tabular}

Kadar kafein yang dihasilkan dari proses ekstraksi sampel dengan penambahan pelarut etil asetat ditunjukkan pada tabel 3 berikut.

Tabel 3 Kadar kafein dalam sampel dengan penambahan etil asetat

\begin{tabular}{|c|c|c|c|c|}
\hline Sampel & Abs & $\begin{array}{c}\text { Konsentrasi } \\
\text { (mg/l) }\end{array}$ & $\begin{array}{c}\text { \% } \\
\text { Kafein }\end{array}$ & $\begin{array}{c}\text { Rata- } \\
\text { Rata }\end{array}$ \\
\hline \multirow{3}{*}{$\begin{array}{c}\text { Biji } \\
\text { Cokelat }\end{array}$} & 1,407 & 25,236 & 0,336 & \\
\cline { 2 - 4 } & 1,403 & 25,163 & 0,335 & \multirow{2}{*}{0,336} \\
\cline { 2 - 4 } & 1,405 & 25,200 & 0,336 & \\
\hline \multirow{3}{*}{ Biji Kopi } & 3,526 & 63,763 & 0,850 & \multirow{3}{*}{0,850} \\
\cline { 2 - 4 } & 3,517 & 63,600 & 0,848 & \\
\cline { 2 - 4 } & 3,544 & 64,09 & 0,854 & \\
\hline \multirow{2}{*}{$\begin{array}{c}\text { Daun } \\
\text { Teh }\end{array}$} & 3,492 & 63,145 & 0,841 & \multirow{2}{*}{0,838} \\
\cline { 2 - 4 } & 3,472 & 62,781 & 0,837 & \\
\cline { 2 - 4 } & 3,488 & 62,709 & 0,836 & \\
\hline
\end{tabular}

Berdasarkan tabel 2 dan 3 kadar kafein paling tinggi terdapat pada biji kopi, sedangkan pelarut organik yang optimum dalam ekstraksi kafein adalah kloroform.

Selanjutnya, pada tahap define dilakukan penyusunan draft lembar kerja inkuiri yang diturunkan dari prosedur eksperimen analisis kafein dari berbagai bahan baku minuman yang telah dilakukan di Laboratorium. Uji kelayakan kepada dosen terhadap format lembar kerja menghasilkan komentar dan saran yang dijadikan acuan dalam proses penyusunan lembar kerja, seperti pada tabel 4.

Setelah mendapatkan saran perubahan terhadap draft lembar kerja, maka dihasilkan nilai $r_{\text {hitung }}$ yang dapat dilihat pada tabel 5 .

Tabel 4 Saran validator terhadap lembar kerja

\begin{tabular}{|c|l|l|l|}
\hline Validator & $\begin{array}{c}\text { Saran } \\
\text { Perbaikan }\end{array}$ & \multicolumn{1}{|c|}{$\begin{array}{c}\text { Sebelum } \\
\text { Perbaikan }\end{array}$} & \multicolumn{1}{|c|}{$\begin{array}{c}\text { Setelah } \\
\text { Perbaikan }\end{array}$} \\
\hline 1 & Di bagian & Kafein secara & Pernahkah kalian \\
& awal & alami ada di & mengonsumsi dari \\
& wacana & dalam biji & minuman kopi, dan \\
& harus & cokelat, kopi, & cokelat, kopi, dena \\
& memberika & dan daun teh. & teh? Mengapa \\
\hline
\end{tabular}




\begin{tabular}{|c|c|c|c|}
\hline & $\begin{array}{l}\mathrm{n} \text { stimulus } \\
\text { sehingga } \\
\text { dapat } \\
\text { dikatakan } \\
\text { sebagai LK } \\
\text { inkuiri. }\end{array}$ & $\begin{array}{l}\text { Jika } \\
\text { mengonsumsi } \\
\text { minuman yang } \\
\text { bberkafein ini } \\
\text { akan timbul } \\
\text { rasa segar. } \\
\text { Oleh karena } \\
\text { itu, ketika } \\
\text { meminum } \\
\text { cokelat, kopi, } \\
\text { dan teh akan } \\
\text { timbul rasa } \\
\text { ketagihan. }\end{array}$ & $\begin{array}{l}\text { sebagian besar } \\
\text { masyarakat lebih } \\
\text { menyukai } \\
\text { minuman kopi, teh } \\
\text { atau hot chocolate } \\
\text { dibandingkan } \\
\text { dengan air putih? } \\
\text { Apakah ada } \\
\text { hubungannya } \\
\text { dengan senyawa } \\
\text { yang terkandung } \\
\text { di dalam ketiga } \\
\text { bahan baku } \\
\text { minuman } \\
\text { tersebut? }\end{array}$ \\
\hline 2 & $\begin{array}{l}\text { Setelah } \\
\text { wacana } \\
\text { disajikan, } \\
\text { berikan } \\
\text { perintah } \\
\text { untuk } \\
\text { membuat } \\
\text { simpulan } \\
\text { mengenai } \\
\text { wacana } \\
\text { tersebut } \\
\text { yang akan } \\
\text { memudahk } \\
\text { an dalam } \\
\text { merumuska } \\
\text { n masalah. }\end{array}$ & $\begin{array}{l}\text { - Merumuskan } \\
\text { masalah dan } \\
\text { hipotesis } \\
\text { 1. Berdasarka } \\
\text { n wacana di } \\
\text { atas, } \\
\text { buatlah } \\
\text { rumusan } \\
\text { masalah } \\
\text { yang Anda } \\
\text { ketahui! }\end{array}$ & $\begin{array}{l}\text { - Merumuskan } \\
\text { masalah dan } \\
\text { hipotesis } \\
\text { 1. Berdasarkan } \\
\text { wacana di atas, } \\
\text { buatlah } \\
\text { simpulan yang } \\
\text { Anda ketahui }\end{array}$ \\
\hline
\end{tabular}

Terlihat pada Tabel 5 bahwa semua pernyataan pada lembar kerja menghasilkan nilai $r_{\text {hitung }}>0,3$. Hal ini didukung juga dengan hasil uji kelayakan kepada mahasiswa menunjukkan nilai rata-rata $r_{\text {hitung }}>0,3$ yaitu 0,835 sehingga lembar kerja yang telah dibuat dinyatakan layak atau sudah memenuhi syarat uji kelayakan (Sugiyono, 2010: 353).

Dalam lembar kerja ini, terdapat pertanyaanpertanyaan yang mengarahkan mahasiswa untuk bekerja maksimal baik secara individu maupun kelompok seperti pada tahap melakukan dan menganalisis data percobaan. Melalui tahap ini menunjukkan bahwa bekerja secara kelompok dapat membantu dalam menyelesaikan semua kegiatan atau perintah pada lembar kerja agar dapat memecahkan suatu masalah yang sedang diselidiki (Eggen \& Kauchak dalam Maryati, dkk., 2015: 182)

Berdasarkan semua data yang didapatkan, lembar kerja berbasis inkuiri yang telah dikembangkan termasuk kedalam kategori valid, sehingga dapat dikatakan lembar kerja ini sudah ideal digunakan sebagai alat bantu pada proses pembelajaran praktikum Kimia Organik.

\section{Tabel 5 Hasil uji kelayakan lk kepada dosen}

\begin{tabular}{|c|c|c|c|c|}
\hline No & Pernyataan & rhitung & $\mathbf{r}_{\text {kritis }}$ & Ket. \\
\hline 1 & $\begin{array}{l}\text { Wacana yang diberikan } \\
\text { membantu mahasiswa } \\
\text { untuk memaparkan } \\
\text { pengetahuannya } \\
\text { mengenai analisis } \\
\text { kafein dari berbagai } \\
\text { bahan baku minuman, } \\
\text { sehingga dapat } \\
\text { menyimpulkan wacana } \\
\text { dengan tepat. }\end{array}$ & 0,750 & 0,3 & Valid \\
\hline 2 & $\begin{array}{l}\text { Wacana yang disajikan } \\
\text { membantu mahasiswa } \\
\text { untuk dapat membuat } \\
\text { pertanyaan mengenai } \\
\text { percobaan. }\end{array}$ & 0,834 & 0,3 & Valid \\
\hline 3 & $\begin{array}{l}\text { Wacana yang disajikan } \\
\text { membantu mahasiswa } \\
\text { untuk dapat membuat } \\
\text { hipotesis untuk } \\
\text { menjawab pertanyaan } \\
\text { mengenai percobaan. }\end{array}$ & 0,916 & 0,3 & Valid \\
\hline 4 & $\begin{array}{l}\text { Wacana yang disajikan } \\
\text { dalam lembar kerja } \\
\text { membantu mahasiswa } \\
\text { untuk menentukan } \\
\text { variabel-variabel yang } \\
\text { diteliti, sehingga dapat } \\
\text { merancang percobaan } \\
\text { dengan tepat. }\end{array}$ & 0,916 & 0,3 & Valid \\
\hline 5 & $\begin{array}{l}\text { Wacana dalam lembar } \\
\text { kerja membantu } \\
\text { mahasiswa untuk dapat } \\
\text { merancang percobaan. }\end{array}$ & 0,916 & 0,3 & Valid \\
\hline 6 & $\begin{array}{l}\text { Pertanyaan yang } \\
\text { diberikan pada lembar } \\
\text { kerja membantu } \\
\text { mahasiswa dalam } \\
\text { mengolah data } \\
\text { percobaan. }\end{array}$ & 0,916 & 0,3 & Valid \\
\hline 7 & $\begin{array}{l}\text { Pertanyaan yang } \\
\text { diberikan pada lembar } \\
\text { kerja membantu } \\
\text { mahasiswa dalam } \\
\text { menyimpulkan } \\
\text { mengenai percobaan. }\end{array}$ & 0,834 & 0,3 & Valid \\
\hline & Rata-rata & 0,868 & 0,3 & Valid \\
\hline
\end{tabular}

\section{KESIMPULAN}

Lembar kerja berbasis inkuiri disusun melalui dua tahapan, yaitu tahap perencanaan (define) dan 
tahap pengembangan (develop). Pada tahap perencanaan dihasilkan prosedur analisis kafein secara kualitatif dengan metode Parry, pemisahan senyawa kafein dan analisis kuantitatif dengan spektrofotometer UV-Vis. Pada tahap pengembangan dihasilkan lembar kerja berbasis inkuiri diturunkan dari prosedur analisis kafein yang telah dilakukan di Laboratorium. Lembar kerja inkuiri hasil pengembangan memiliki karakteristik: adanya wacana, pertanyaan dan tugas yang mendorong kegiatan berinkuiri. Dilengkapi dengan rubrik penilaian untuk mengukur proses dan produk yang dihasilkan oleh peserta didik.

Lembar kerja berbasis inkuiri pada analisis kafein dari berbagai bahan baku minuman dinyatakan layak digunakan dengan nilai rata-rata rhitung $^{0,8}$.

Hasil analisis kafein dari berbagai bahan baku minuman menunjukkan kondisi optimum proses ekstraksi dicapai dengan menggunakan pelarut kloroform yaitu biji kopi memiliki kadar kafein tertinggi dengan nilai rata-rata sebesar 1,007\%.

\section{DAFTAR PUSTAKA}

Arwangga, A.F., Asih, I.A.R.A., Sudiarta, I.W. (2016). Analisis Kandungan Kafein di Desa Sesaot Narmada dengan Menggunakan Spektrofotometri UV-Vis. Jurnal Kimia, 10, (1), 110-114.

\section{Depkes RI. (1995). Farmakope Indonesia (Ed.Keempat).Jakarta: Departemen Kesehatan Republik Indonesia.}

Erwin, K. (2009). Sejarah dari Secangkir Teh. Jakarta: Gramedia.

Joyce, B., Weil, M. Dan Calhoun, E.(2009). Models of Teaching, Jilid 1 (Ed.Kedelapan). Terjemahan oleh Achmad Fawaid dan Ateilla Mirza. Yogyakarta: Pustaka Pelajar.

Maramis, R.K., Citraningtyas, G., dan Wehantouw, F. (2013). Analisis Kafein dalam Kopi Bubuk di Kota Manado Menggunakan Spektrofotometri UV-Vis. Jurnal Ilmiah Farmasi, 2, (4), 122-128.

Maryati, dkk. (2015). Lembar Kerja Siswa Eksperimen Dan Non Eksperimen Berbasis Inkuiri Terstruktur pada Materi Pergeseran Kesetimbangan Kimia. Prosiding Simposium Nasional Inovasi Dan
Pembelajaran Sains. Bandung: Program Studi Pendidikan MIPA UPI.

Sugiyono. (2010). Metode Penelitian Kuantitatif Kualitatif dan R\&D. Bandung: Alfabeta.

Varma, D. (2010). Batch Solven Extraction of Caffeine From MCBC2. Thesis. Malaysia: University Malaysia Pahang. [Online]. Tersedia: http://www.umpir.ump.edu.my/CD5520_DI NESH_VARMA/html. [Diakses 30 Desember 2015]

Yunita. (2012). Panduan Pengelolaan Laboratorium Kimia. Bandung: CV. Insan Mandiri. 